\title{
Metal Supported SOFCs for Mobile Applications using Hydrocarbon Fuels
}

\author{
Hagen, Anke; Sun, Xiufu; Sudireddy, Bhaskar Reddy; Persson, Åsa Helen
}

Published in:

Journal of the Electrochemical Society

Link to article, DOI:

10.1149/1945-7111/ab9b9d

Publication date:

2020

Document Version

Peer reviewed version

Link back to DTU Orbit

Citation (APA):

Hagen, A., Sun, X., Sudireddy, B. R., \& Persson, Å. H. (2020). Metal Supported SOFCs for Mobile Applications using Hydrocarbon Fuels. Journal of the Electrochemical Society, 167(10), [104510].

https://doi.org/10.1149/1945-7111/ab9b9d

\section{General rights}

Copyright and moral rights for the publications made accessible in the public portal are retained by the authors and/or other copyright owners and it is a condition of accessing publications that users recognise and abide by the legal requirements associated with these rights.

- Users may download and print one copy of any publication from the public portal for the purpose of private study or research.

- You may not further distribute the material or use it for any profit-making activity or commercial gain

- You may freely distribute the URL identifying the publication in the public portal 


\title{
Metal Supported SOFCs for Mobile Applications using Hydrocarbon Fuels
}

\author{
A. Hagen ${ }^{\mathrm{a}}$, X. Sun ${ }^{\mathrm{a}}$, B. R. Sudireddy ${ }^{\mathrm{a}}$, and Å. H. Persson ${ }^{\mathrm{a}}$ \\ ${ }^{a}$ Department of Energy Conversion and Storage, Technical University of Denmark, 2800 \\ Kgs. Lyngby, Denmark
}

\begin{abstract}
Metal supported solid oxide fuel cell (MSC) technology has a significant potential for mobile applications, due to high electrical efficiencies, fuel flexibility, cheap materials, and mechanical robustness. The MSC concept in the current study relies on scalable, ceramic processing methodology. Two MSC generations with different anodes, one with a FeCr-ScYSZ-based anode backbone and one with a FeCr-titanate based anode backbone, both infiltrated with GDC and Ni electro catalysts, were tested using methane containing fuel. It was found that the internal reforming activity of the anodes is reduced as compared to state-of-the-art Nicermet anodes, due to the lower $\mathrm{Ni}$ content in the anodes of the MSCs. Still, power densities of ca. $0.22 \mathrm{~W} / \mathrm{cm}^{2}$ were obtained at $650{ }^{\circ} \mathrm{C}$ in a methane/steam fuel and long-term tests at medium to high fuel utilization were successfully demonstrated on the titanate based MSC.
\end{abstract}

\section{Introduction}

Metal supported solid oxide fuel cell (SOFC) technology (MSC) has attractive features for mobile / transport applications. It combines the high electrical efficiencies of SOFCs with cheap materials and higher mechanical robustness of the MSC concept. MSC concepts include for example perforated ferritic steel supports $(1,2,3)$ or tape cast metal supports (4).

The concept of MSCs based on tape casting, sintering in reducing atmosphere, and infiltration of electro catalyst has a number of attractive features, such as scalability to large scale, thin cells resulting high power per unit area/volume, which is an important factor for the limited space in vehicles, and less materials costs. Challenges that have to be mastered include the structuring and sintering properties (porosity, dense electrolyte, etc.). MSC concepts with tape cast supports have demonstrated high power density of 1.2 $\mathrm{W} / \mathrm{cm}^{2}$ at $750{ }^{\circ} \mathrm{C}(4,5)$. Furthermore, such cells provided good long-term stability under constant operation over up to ca. $3000 \mathrm{~h}$ with hydrogen fuel $(4,5)$. Challenges include corrosion. At high steam content and high temperature, the $\mathrm{Cr}_{2} \mathrm{O}_{3}$ scale on the $\mathrm{FeCr}$ surface can no longer offer the required protection to $\mathrm{FeCr}$ finally resulting in breakaway corrosion (6), i.e., the result is the formation of $\mathrm{Fe}_{2} \mathrm{O}_{3}$, which is associated with volumetric expansion and loss of electronic conductivity. Furthermore, Ni inter diffusion, particularly at high steam content, which is the case when operating at high fuel utilization, has been a problem (7). If $\mathrm{Ni}$ diffuses into $\mathrm{FeCr}$, the ferritic $\mathrm{FeCr}$ transforms into austenitic $\mathrm{FeCr}$ and this transformation is associated with volume changes that can result in interfacial stresses and microstructural instability $(8,9,10)$. In order to overcome 
these degradation mechanisms, alternative anodes were developed. Promising alternative anodes are based on titanates, for example lanthanum strontium iron nickel titanate (LSFNT). These titanates showed potential as anodes due to their reasonably good electronic conductivity and chemical stability under the SOFC operating conditions. MSCs with such anodes showed a reduced peak performance compared to the generation with FeCr-ScYSZ based anodes by ca. 30\% $(11,12)$. On the other hand, they were still more active than other alternative anodes to state-of-the-art (SoA) Ni-cermets. Initial durability tests using hydrogen fuel showed promising results. The improved stability was ascribed an improved corrosion resistance (13).

For mobile and stationary applications, not only hydrogen but also carbon containing fuels are interesting in order to take advantage of the fuel flexibility of SOFCs, of highdensity fuels, and of operation at higher fuel utilization. For mobile applications, a combination with a battery is attractive; the SOFC thus acting as range extender. Nissan has introduced a vehicle based on this concept, utilizing a carbon neutral fuel from existing fueling infra structure (14). The integration of SOFC into electrical vehicles and use of alternative, high-density fuels was evaluated in a model study by Bessekon et al. (15). The advantages of driving electric vehicles was utilized together with the long driving range and fast fueling with an existing infra structure, made available through the SOFC. In the study, a Nissan Leaf electrical vehicle was used as basis. The battery size was reduced by $50 \%$, which results in significant reduction of weight and materials costs. Instead, a 301 tank and a commercially available SOFC was integrated in the power train model. Using liquefied petroleum gas (LPG), a range extension towards values common for internal combustion engine vehicles were simulated in this setup (823 km vs. $170 \mathrm{~km}$ of the original vehicle (15)). In order to achieve even longer ranges, the tank size could be increased, which is a cheaper option than increasing the battery size. Furthermore, SOFC stacks with higher performance could be integrated.

Detailed knowledge about the long-term behavior of MSCs under conditions interesting for mobile applications, such as use of carbon containing fuel and high fuel utilization is lacking, i.e. how much the well-known fuel flexibility of SOFC applies to current MSC concepts. The current study investigated performance and durability of MSCs in hydrogen and in methane/steam fuel with stepwise increasing the fuel utilization. Special interest is on the activity of two different anode structures, YSZ-MSC and LSFNT-MSC, for internal reforming. The composite anode backbones are designed to provide the ionic (YSZ) and electronic ( $\mathrm{FeCr}$ ) conductivity together with good adhesion with the metal support and electrolyte in case of YSZ-MSC backbones and good adhesion with metal support and additional electronic conductivity in case of LSFNTMSC. The performance and durability was characterized in detail by electrochemical impedance spectroscopy (EIS).

\section{Experimental}

\section{$\underline{\text { MSCs }}$}

Two types of MSCs were tested, one version with an anode backbone of Fe-22 wt.\% $\mathrm{Cr}(\mathrm{FeCr})-\left(\mathrm{Y}_{2} \mathrm{O}_{3}\right)_{0.01}\left(\mathrm{Sc}_{2} \mathrm{O}_{3}\right)_{0.1}\left(\mathrm{ZrO}_{2}\right)_{0.89}$ (ScYSZ), which is denoted as YSZ-MSC and one with a FeCr-LSFNT ( $\left.\mathrm{La}_{0.4} \mathrm{Sr}_{0.4} \mathrm{Fe}_{0.03} \mathrm{Ni}_{0.03} \mathrm{Ti}_{0.94} \mathrm{O}_{3}\right)$ based anode backbone, denoted as 
LSFNT-MSC. The cell design is schematically illustrated in Figure 1. Both versions are based on a FeCr support. The metal support (ca. $300 \mu \mathrm{m}$ ), anode backbone (ca. $15 \mu \mathrm{m}$ ), and electrolyte (ca. $10 \mu \mathrm{m}$ ) layers were fabricated using tape casting. The layers were laminated and co-sintered in reducing environment at temperatures between $1200{ }^{\circ} \mathrm{C}-$ $1300{ }^{\circ} \mathrm{C}$ to form the half-cell. Subsequently, the anode backbone was infiltrated with aqueous metal nitrates of $\mathrm{Ni}, \mathrm{Ce}$ and $\mathrm{Gd}$ to form the Ni-Gd-doped $\mathrm{CeO}_{2}$ (GDC) electro catalyst upon subsequent heat treatment. The procedure for infiltration is described elsewhere (16). The ratio of Ni to GDC was 10:90 by weight. After three cycles of infiltration, the electro catalyst loading was $0.008-0.010 \mathrm{~g} / \mathrm{cm}^{2}$ resulting in ca. $0.8-1.0$ $\mathrm{mg} / \mathrm{cm}^{2}$ of Ni. After the integration of electro catalyst, a Ce $0.9 \mathrm{Gd}_{0.1} \mathrm{O}_{1.95}$ barrier layer (1-2 $\mu \mathrm{m})$ was deposited using physical vapor deposition, to prevent the reaction between electrolyte and cathode. Finally, the LSC ((La0.6Sro.4)0.99 $\left.\mathrm{CoO}_{3-\delta}\right)$ cathode (ca. $\left.15 \mu \mathrm{m}\right)$ was deposited using screen printing. Figure 2 shows the microstructures of the two cell versions before testing. The cathode was sintered in-situ during start-up of the cell, prior to the electrochemical cell testing (17). The cell size was $25 \mathrm{~cm}^{2}$ with an active area of 16 $\mathrm{cm}^{2}$.

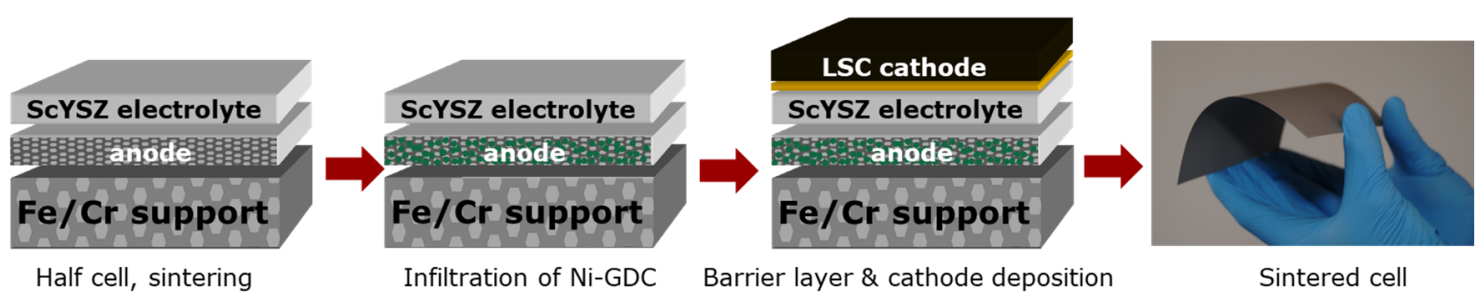

Figure 1. Illustration of fabrication of the MSC types used in this study.

a)

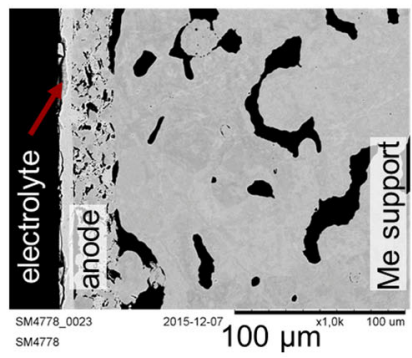

b)

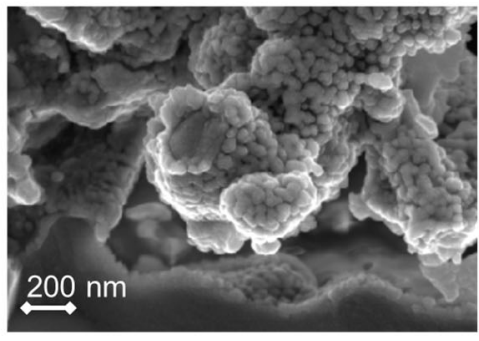

c)

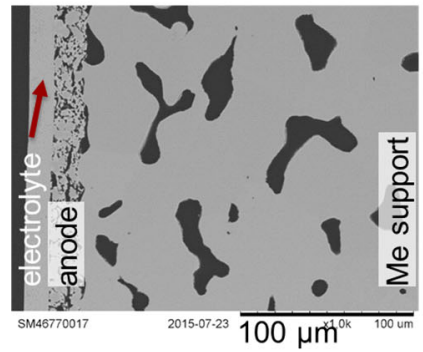

Figure 2. SEM microscopy of (a) YSZ-MSC half-cell, $100 \mu \mathrm{m}$ scale, (b) YSZ-MSC anode with infiltrated Ni/GDC nano particles, $200 \mathrm{~nm}$ scale, and (c) LSFNT-MSC halfcell, $100 \mu \mathrm{m}$ scale.

\section{$\underline{\text { Cell testing }}$}

For electrochemical testing, the cells were placed in a ceramic test house. Ni and Au meshes were used as contact and current collector components on the anode and cathode side, respectively. The cells were sealed at their edges using glass (see Figure 3a). 
The tests were initiated by heating the cells to $800{ }^{\circ} \mathrm{C}$ with a heating rate of $1{ }^{\circ} \mathrm{C} / \mathrm{min}$ and holding for 5 hours at $800{ }^{\circ} \mathrm{C}$ for in-situ sintering of the cathode. During heating up, $20 \mathrm{~L} / \mathrm{h}$ of $5 \% \mathrm{H}_{2}+\mathrm{N}_{2}$ were supplied to the anode compartment and $40 \mathrm{~L} / \mathrm{h}$ of air was supplied to the cathode compartment. Initial iV curves and electrochemical impedance spectra (EIS) were recorded from 750 to $650{ }^{\circ} \mathrm{C}$, with $24 \mathrm{~L} / \mathrm{h}$ fuel flow with different hydrogen/steam fuel ratios (and with $18 \mathrm{~L} / \mathrm{h}$ methane/steam fuel with a ratio of 0.5 ), according to a standardized protocol (denoted as fingerprint). Afterwards, one LSFNTMSC cell was set to durability conditions with hydrogen and another with methane/steam at $650{ }^{\circ} \mathrm{C}$. After the durability test, the fingerprint characterization was repeated. The test protocol is illustrated in Figure $3 \mathrm{~b}$.

The DRT analyses with the Fourier transform method was performed with the inhouse developed Ravdav software (18). The Hanning window function was chosen for smoothing the generated DRT data and the filter window size was chosen based on experience and studies on similar types of cells (19).

a)

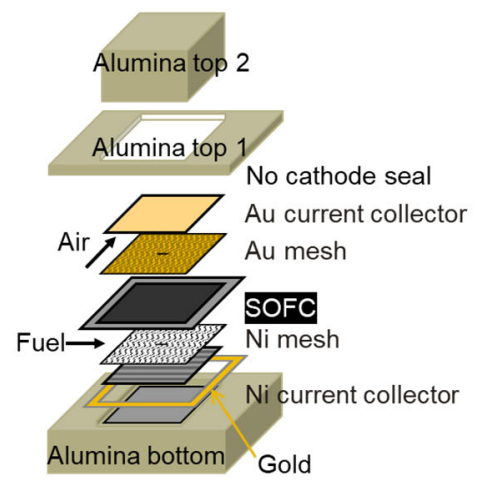

b)

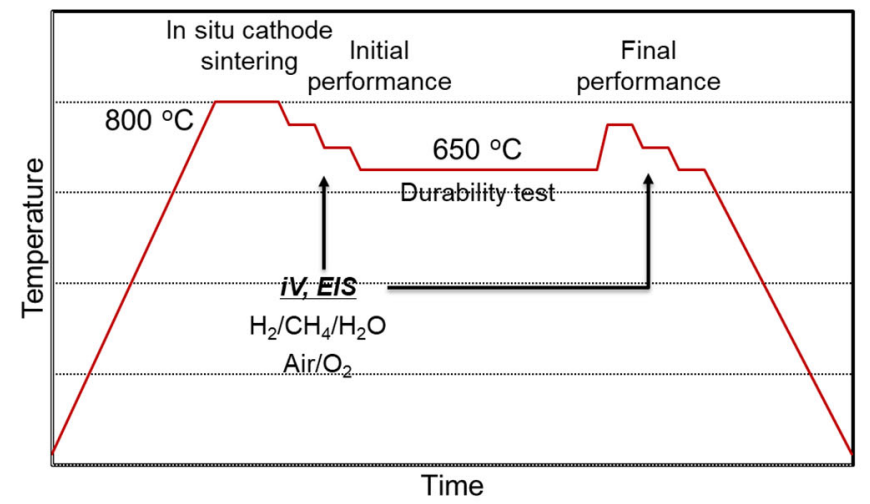

Figure 3. Illustration of test house (a) and test protocol (b).

\section{Results}

\section{$\underline{\text { Initial performances }}$}

The initial performance of all cells was characterized by iV curves in hydrogen (with $20 \%$ steam) and in methane/steam fuel. The use of hydrogen serves the verification of the test setup, such as the gas tightness, i.e. if the theoretic open circuit voltage (OCV) is reached (1041 mV under the current conditions in hydrogen fuel with $20 \%$ steam), if contacting of the cell in the setup is intact, and for the comparison between all cell types and generations. Deviation from this OCV would for example indicate a leaky test setup.

When methane is fueled directly, steam is added to provide a reforming agent and with a ratio, which should prevent carbon formation. Typically, a steam to methane ratio of two is applied. Under these conditions, methane is reformed (equation [1]) and the water gas shift reaction occurs (equation [2]). The resulting equilibrium gas mixture consists of $\mathrm{CO}, \mathrm{CO}_{2}, \mathrm{H}_{2} \mathrm{O}$, and $\mathrm{H}_{2}$, yielding an $\mathrm{OCV}$ of $1049 \mathrm{mV}$ at $650{ }^{\circ} \mathrm{C}$ (based on the 
Nernst equation). Deviations from this OCV value would indicate incomplete methane conversion, i.e. a gas composition not corresponding to equilibrium.

$$
\begin{aligned}
& \mathrm{CH}_{4}+\mathrm{H}_{2} \mathrm{O} \rightleftharpoons \mathrm{CO}+3 \mathrm{H}_{2} \\
& \mathrm{CO}+\mathrm{H}_{2} \mathrm{O} \rightleftharpoons \mathrm{CO}_{2}+\mathrm{H}_{2}
\end{aligned}
$$

Figure 4 shows the iV curves of the YSZ-MSC at $650{ }^{\circ} \mathrm{C}$ in the two fuel gas mixtures. The measured OCV in hydrogen with $20 \%$ steam was $1040 \mathrm{mV}$, i.e. very close to the theoretic value, thus validating the test set-up and confirming that the cell behaves as expected. The maximum power output was $0.5 \mathrm{~W} / \mathrm{cm}^{2}$ at $0.75 \mathrm{~A} / \mathrm{cm}^{2}$.

When using methane / steam fuel, the OCV was only $886 \mathrm{mV}$ and thus significantly lower than the theoretic value of $1049 \mathrm{mV}$. This is a clear indication for an incomplete methane conversion. The reason is most probably the much smaller Ni-concentration in the anode as compared to SoA (state-of-the-art) anode supported SOFCs with a Ni/YSZ cermet anode, even though the concentration alone cannot always account for catalytic activity. Infiltrated $\mathrm{Ni}$ in the present study will have relatively higher surface area per unit weight compared to the bulk Ni in SoA Ni/YSZ cells. However, the Ni/YSZ cells contain ca. $3.5 \mathrm{~g} / \mathrm{cm}^{2} \mathrm{Ni}$ in the active anode (in addition, $\mathrm{Ni}$ is also present in the thick anode support layer) and contain thus a factor of more than thousand more Ni than the MSCs in this study, which provides significant more active sites, even though only the surface of these Ni particles would contribute to methane conversion. The obtained value of 886 $\mathrm{mV}$ would correspond to ca. 3.5\% methane conversion on the YSZ-MSC anode, only. Such low conversion translates directly into small concentrations of hydrogen (and $\mathrm{CO}$ ) for the electrochemical reactions and leads to a very fast cell voltage drop during iV curve recording, which was so significant already below $0.1 \mathrm{~A} / \mathrm{cm}^{2}$, that the cell voltage immediately exceeded the test station safety cut-off voltage of $600 \mathrm{mV}$. This fast cell voltage drop corresponds to a severe fuel starvation

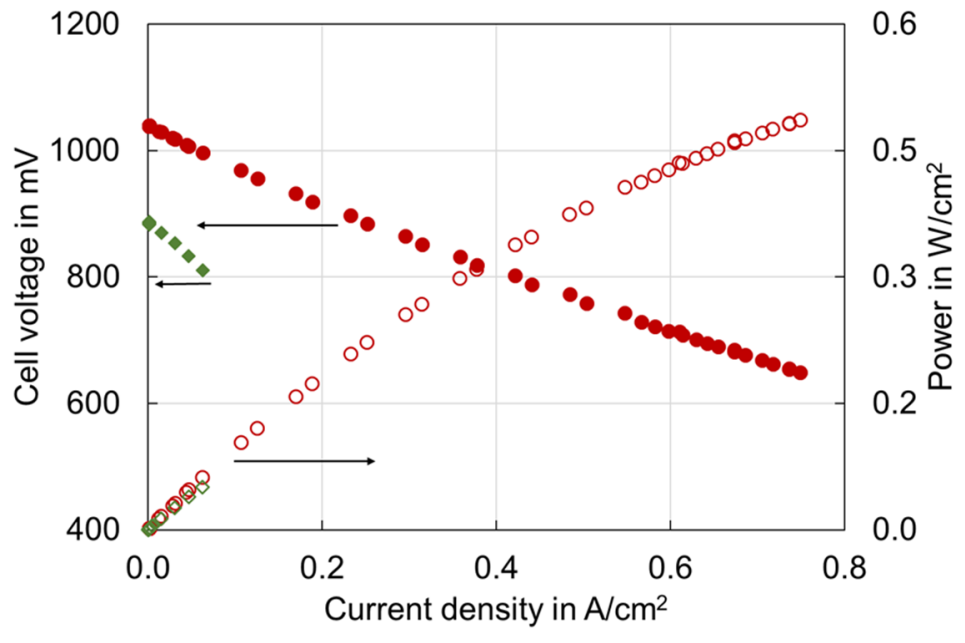


Figure 4. YSZ-MSC, initial iV curves (full symbols, left axis) and power curves (open symbols, right axis) at $650{ }^{\circ} \mathrm{C}$, air to the cathode and either hydrogen $/ 20 \%$ steam (red circles) or methane/steam with a ratio of $1 / 2$ (green rhombs) to the anode.

Figure 5 shows the initial performance of the LSFNT-MSC in hydrogen/steam and in methane/steam fuel at $650{ }^{\circ} \mathrm{C}$. The OCV in hydrogen with $20 \%$ steam was $1038 \mathrm{mV}$, which is only a $3 \mathrm{mV}$ difference to the theoretic voltage. This result confirms a tight setup, i.e. intact sealing. The maximum power output was $0.37 \mathrm{~W} / \mathrm{cm}^{2}$ at a current density of $0.6 \mathrm{~A} / \mathrm{cm}^{2}$ (for comparison, the power output of the YSZ-MSC was 0.44 $\mathrm{W} / \mathrm{cm}^{2}$ at this current density). The power output was thus smaller than with the YSZMSC, which confirms earlier findings $(11,12)$.

Using methane/steam fuel on the LSFNT-MSC, a smaller than theoretic OCV was observed; only $944 \mathrm{mV}$. The lower OCV is again due to the incomplete conversion of methane. The measured value corresponds to a methane conversion of ca. $17 \%$, which is still better than what was found in the test with the YSZ-MSC with the same fuel (see Figure 4). Consequently, both MSC anodes with a smaller content of $\mathrm{Ni}\left(0.8-1 \mathrm{mg} / \mathrm{cm}^{2}\right)$, are not sufficiently active for the internal methane reforming reaction (and probably also the water gas shift reaction). The higher methane conversion at the LSFNT-MSC as compared to the YSZ-MSC could be due to a potential additional catalytic effect of $\mathrm{Ni}$ (3 mol.\%) in the LSFNT. The LSFNT perovskite material is designed to exsolute Ni and/or Fe in reducing atmosphere at optimum temperature $\left(700-900{ }^{\circ} \mathrm{C},(12)\right)$ and this exsoluted $\mathrm{Ni}$ might contribute to the improved methane conversion activity $(20,21)$. In addition to this catalytic effect, the observed improvement could also be due to the different interaction behavior of the infiltrated Ni with the LSFNT-MSC backbone compared to YSZ-MSC backbone. Still, operating this fuel cell, not as much hydrogen and CO are formed for the electrochemical reaction as compared to SoA Ni/YSZ anodes when increasing the current density. The resulting real fuel utilization is higher and fuel starvation might occur earlier, which is also visible in the iV curve for methane /steam fuel in Figure 5. The curve is bending down already around $0.4 \mathrm{~A} / \mathrm{cm}^{2}$, while there is no sign for fuel starvation in hydrogen $/$ steam fuel at $0.6 \mathrm{~A} / \mathrm{cm}^{2}$ and beyond.

On the other hand, the electrochemical behavior in terms of area specific resistance (ASR), determined as local slope at a current density of $0.06 \mathrm{~A} / \mathrm{cm}^{2}$, is similar in both fuels. The values are $0.80 \Omega \mathrm{cm}^{2}$ and $0.85 \Omega \mathrm{cm}^{2}$ in hydrogen/steam and methane/steam, respectively. The LSFNT-MSC is thus a good candidate for application and the reduced performance in hydrogen as compared to the YSZ-MSC is compensated by the better performance in methane. 


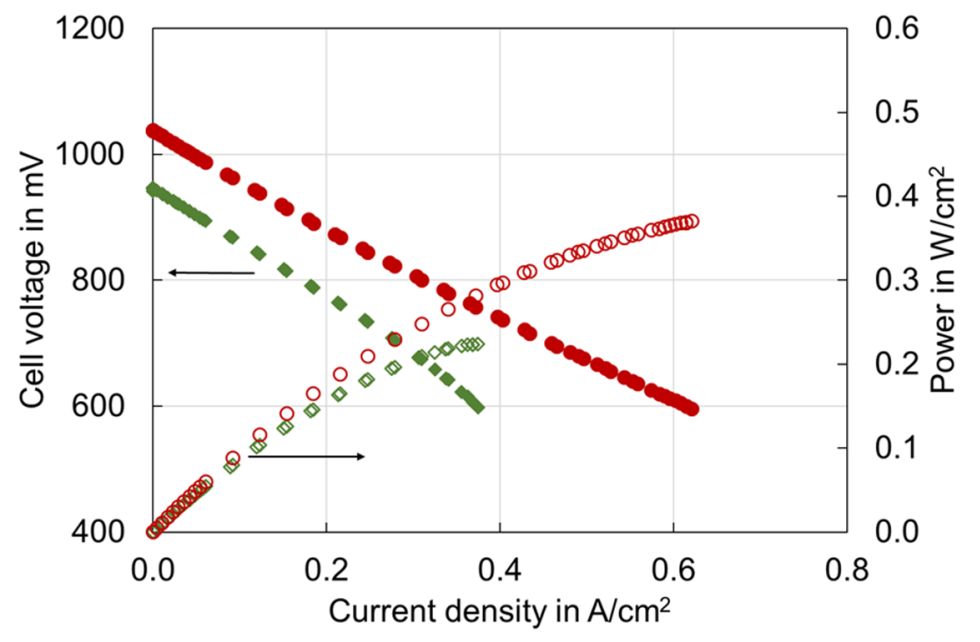

Figure 5. LSFNT-MSC, initial iV curves (full symbols, left axis) and power curves (open symbols, right axis) at $650{ }^{\circ} \mathrm{C}$, air to the cathode and either hydrogen $/ 20 \%$ steam (red circles and blue triangles) or methane/steam with a ratio of $1 / 2$ (green rhombs) to the anode.

Using methane as fuel directly in an SOFC might be desired from a system point of view, as the internal reforming reaction provides cooling during the SOFC operation. In order to improve the catalytic activity of the two MSC types for methane reforming, the $\mathrm{Ni}$ loading of the anodes could be increased through more infiltration cycles or higher $\mathrm{Ni}$ content in the infiltration solution (higher solid loading of the infiltrate). Another option is to introduce catalytically active stack components such as contact/gas distribution layers. For example, metal foams have been studied as stack components with good contacting properties. Such foams have a large surface area, which makes them suitable catalysts (22). An alternative to the internal reforming of the methane fuel is to carry out the catalytic reforming prior to the SOFC stack through installation of a pre-reformer.

The iV curves, recorded during the initial characterization in either hydrogen or methane containing fuel, revealed different behaviors of the two MSC types with YSZ or LSFNT containing backbones. The results were therefore evaluated using the EIS fingerprint test protocol, which included change of gas compositions to cathode and anode.

Figure 6 shows the EIS recorded in hydrogen and methane containing fuels on the YSZ-MSC. Significant differences of the polarization resistances are observed when the fuel is changed, while the serial resistances remained the same. The polarization resistance increased in the methane/steam vs. hydrogen/steam fuel, in the low and medium frequency range (see Figure 6). These results indicate increased resistance of the electrode as well as transport processes when fueling methane and steam instead of hydrogen, which may be attributed to the slower fuel electrode kinetics and gas diffusion rates in $\mathrm{CH}_{4}$ reformate gas compared with $\mathrm{H}_{2}$ /steam fuel. 

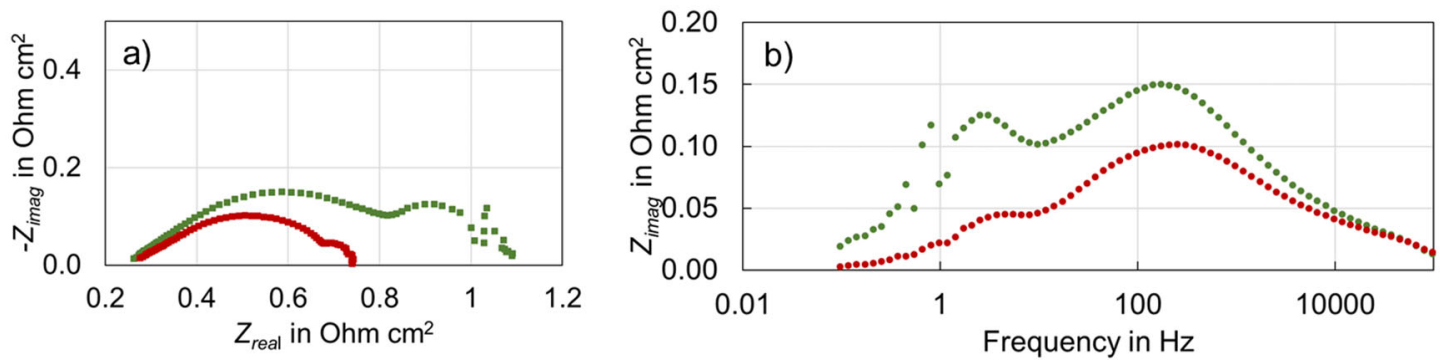

Figure 6. EIS on the YSZ-MSC at $650{ }^{\circ} \mathrm{C}$ and $\mathrm{OCV}$, air to the cathode and hydrogen $/ 20 \%$ steam (red symbols) or methane/steam $=1 / 2$ to the anode (green symbols)

a) Nyquist and b) Bode plot.

Figure 7 shows the EIS recorded in hydrogen and methane containing fuels on the LSFNT-MSC. In this case, the polarization resistances were very close in both fuels. This result confirms the ASR values, which were obtained from the iV curves and which were also very similar in both fuels on this MSC (LSFNT-MSC, see Figure 5). Only minor differences are observed based on the EIS results. The internal methane reforming - even though it is not complete - produces hydrogen (and CO), which behave as if hydrogen is fueled directly. Only in a regime, where not sufficient hydrogen is produced due to the incomplete methane reforming, the LSFNT-MSC experiences lack of fuel and increase of ASR (see Figure 5, higher current densities) as compared to the direct fueling of hydrogen. As the EIS are recorded around OCV, the regime of fuel starvation is not reached.
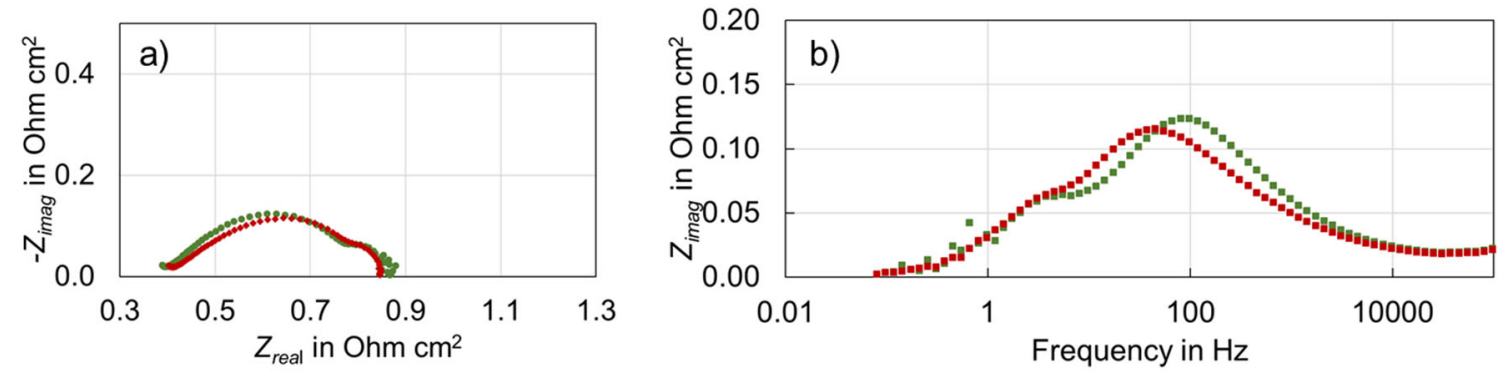

Figure 7. EIS on the LSFNT-MSC at $650{ }^{\circ} \mathrm{C}$ and OCV, air to the cathode and hydrogen $/ 20 \%$ steam (red symbols) or methane/steam $=1 / 2$ to the anode (green symbols) a) Nyquist and b) Bode plot.

A means to identify specific electrode processes is to record EIS under different fuelto-anode and oxygen-partial-pressure-to-cathode compositions and to observe the changes of EIS. In other words, the gas to one electrode is changed while keeping all other conditions constant in order to enable the identification of individual anode and cathode contributions to the total impedance of the cell. Figure 8 shows the results on both MSC types. For a fast visualization of the affected processes in the EIS, a simple difference between the spectra (Bode plots) was calculated and plotted, while for more 
detailed analysis more advanced methods such as distribution of relaxation times (DRT) could be employed.
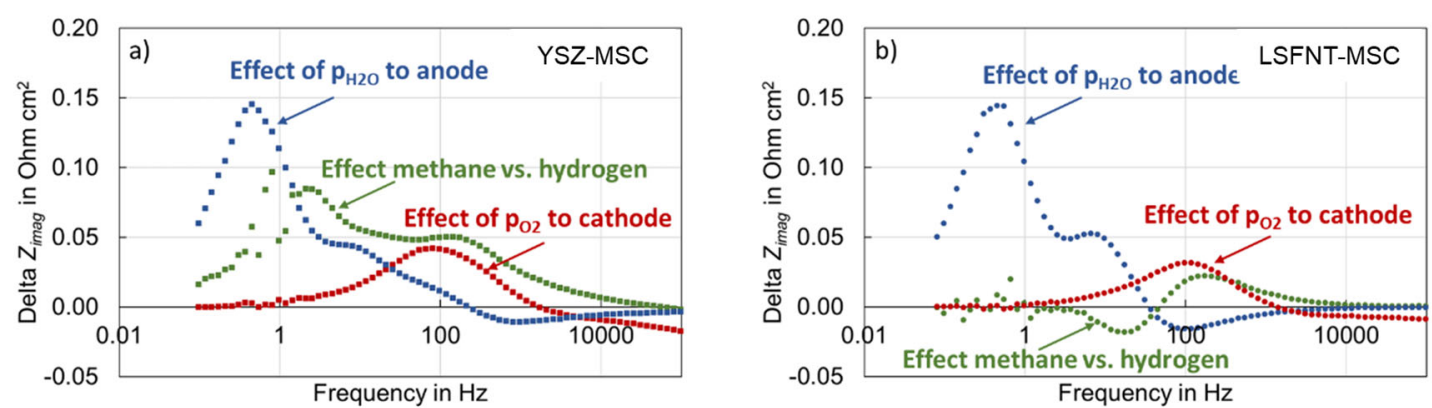

Figure 8. Difference of EIS (Bode plots), $650{ }^{\circ} \mathrm{C}$ and OCV, blue symbols: $20 \%$ steam in hydrogen vs. $4 \%$ steam in hydrogen to anode, green symbols: methane/steam vs. hydrogen $/ 20 \%$ steam to anode, red symbols: air vs. oxygen to cathode, a) on the YSZMSC and b) on the LSFNT-MSC.

When the gas was changed between air and oxygen to the cathode (while sending hydrogen to the anode in all cases), the impedance in the frequency region around $100 \mathrm{~Hz}$ was affected for both MSC types (see Figure 8, red symbols). This indicates that cathode processes are involved in this frequency region and that those are similar in both MSC types. This seems justified because the same cathode type was deposited on both MSC types (LSC). Further, when the degree of humidification of hydrogen to the anode was changed from 4 to $20 \%$, impedance contributions in the frequency ranges of ca. 0.5 and ca. $10 \mathrm{~Hz}$ were affected, on both MSC types. Such low frequency ranges are characteristic for gas conversion and diffusion, respectively. Because both MSC types show similar responses, these two processes seem to proceed in a similar way on the YSZ-MSC and the LSFNT-MSC. This result is due to the two backbones possessing similar structures and the same infiltration procedure of electro catalyst that was applied on both MSCs.

The most distinct difference between the YSZ-MSC and the LSFNT-MSC is the response to changing the fuel from hydrogen to methane based compositions (green symbols in Figure 8). Two main processes are affected on the YSZ-MSC, while there is almost no effect on the LSFNT-MSC. The latter finding is well corresponding with the results of the $\mathrm{iV}$ curves and the EIS-Nyquist and Bode plots (Figure 5 and Figure 7).

More specifically, the frequencies around $3 \mathrm{~Hz}$ and ca. 100-140 Hz change for the YSZ-MSC. As already mentioned, low frequency ranges are characteristic for gas conversion/gas diffusion, while anode processes should be responsible for the higher frequency responses. The increase of gas conversion/diffusion impedance can be explained by the severely suppressed methane reforming reaction, leading to insufficient fuel at the anode, already at the close to OCV conditions of the EIS recording. Diffusion is also hindered in presence of the larger methane molecule as compared to hydrogen. In addition, anode reactions are affected when introducing methane/steam fuel, which might be due to the high steam content present when only a small fraction of methane is converted in the reforming reaction. 


\section{Durability}

Due to the low initial performance of the YSZ-MSC in methane fuel, the durability tests were only carried out with LSFNT-MSCs. Furthermore, the good durability of the YSZ-MSC in hydrogen fuel at low fuel utilization was already demonstrated over $3000 \mathrm{~h}$ in previous studies $(4,5)$.

The LSFNT-MSC was tested in hydrogen fuel for 2000 hours, with several interruptions due to technical challenges (see Figure 9, degradation rates in Table I). During the testing, the fuel utilization (FU) was successively increased from 10 to 42, and finally to $70 \%$. The linear cell voltage degradation rates were $5 \% / 1000 \mathrm{~h}$ at $10 \% \mathrm{FU}$ and $6 \% / 1000 \mathrm{~h}$ at $42 \% \mathrm{FU}$. At the highest FU of $70 \%$, the degradation rate started at ca. $13 \% / 1000 \mathrm{~h}$ during the first ca. $180 \mathrm{~h}$ and started to accelerate afterwards. It thus seems to be a critical FU leading to irreversible degradation of the LSFNT-MSC with hydrogen fuel.

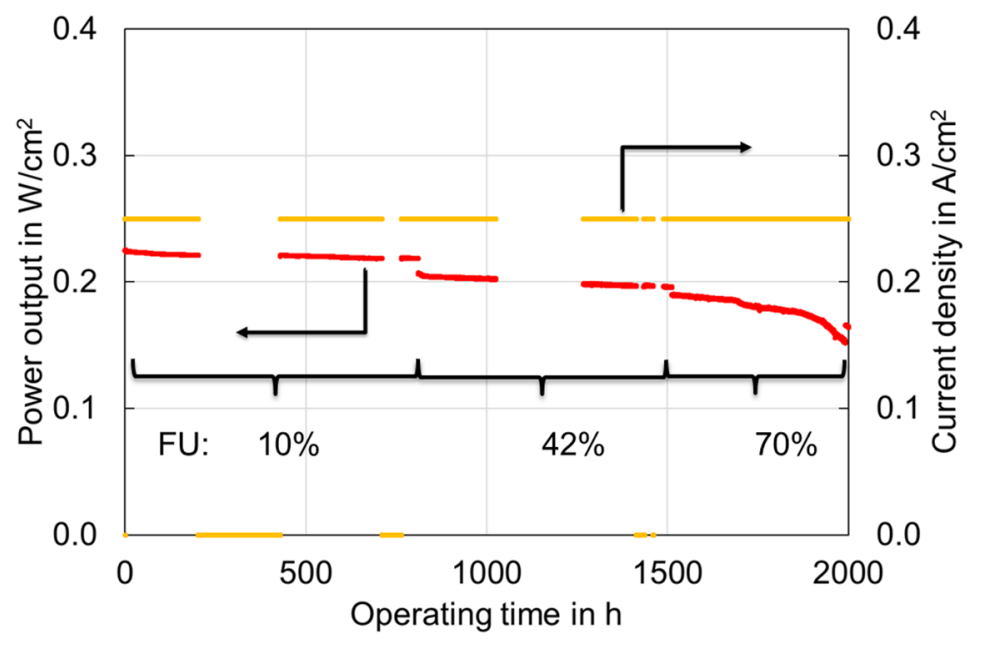

Figure 9. Long-term test of the LSFNT-MSC, power output (red curve, left axis), current density (yellow curve, right axis), $650{ }^{\circ} \mathrm{C}$, air to the cathode and hydrogen $/ 20 \%$ steam.

TABLE I. FUs for the long-term tests of the LSFNT-MSCs in hydrogen or in methane containing fuels and obtained cell voltage degradation rates (expressed at linear degradation rate per $1000 \mathrm{~h}$ ) at $650{ }^{\circ} \mathrm{C}$.

\begin{tabular}{ccc}
\hline Fuel & FU (\%) & Cell voltage degradation rate (\%/1000 h) \\
\hline Hydrogen/steam & 10 & 6 \\
& 42 & 5 \\
Methane/steam & 70 & 13 \\
& 48 & 30 \\
& 60 & accelerated
\end{tabular}

\footnotetext{
* In case of the test with methane/steam fuel, the incomplete methane conversion was considered, i.e. the reduced amount of in situ formed hydrogen. This hydrogen (based on OCV values) was used for calculating the FU.
} 
Another LSFNT MSC was tested for durability in methane/steam fuel. Figure 10 shows the results. For comparison, the fuel flows were adjusted to obtain the same FU as for the case of the test with hydrogen fuel, under the assumption of complete methane reforming, i.e. with the hydrogen content corresponding to the equilibrium. From the OCV and the initial iV curves (see Figure 5) it is clear that the methane conversion was incomplete. This leads to a smaller actual hydrogen content and thus a higher, real FU as compared to a complete methane conversion. In order to achieve the highest FU, the current density was increased because the needed small gas flow rates could not be adjusted with the existing mass flow controllers. The increased current density was still in the range of the linear regime in the $\mathrm{iV}$ curve (Figure 5) and thus no additional large contributions to the resistance were expected. Table I lists the real FUs for the tests in hydrogen and methane containing fuels and the corresponding cell voltage degradation rates. The real FU of the methane containing fuel were determined based on the $\mathrm{H}_{2}$ content calculated from the measured OCV.

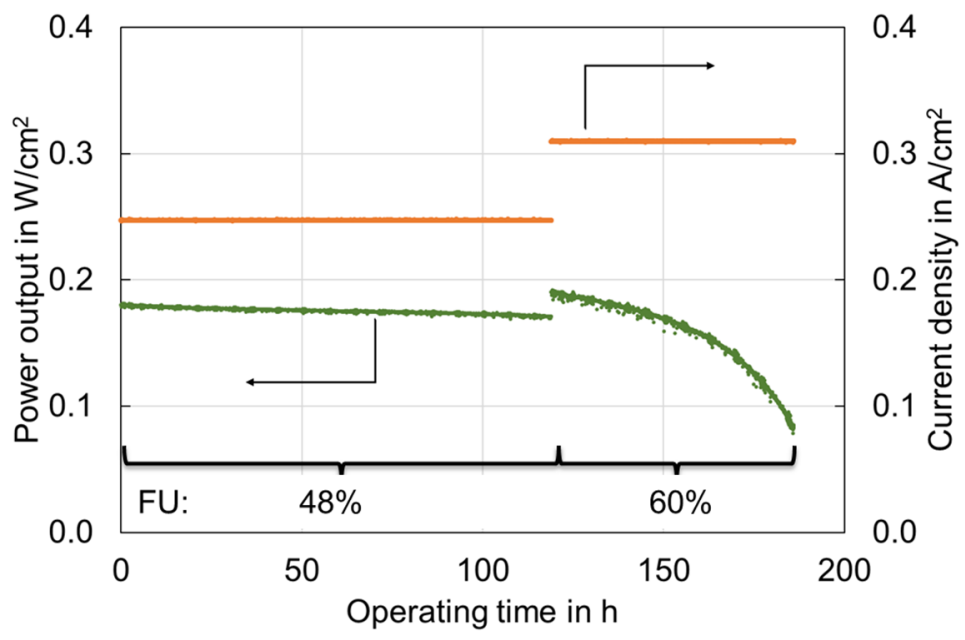

Figure 10. Long-term test of the LSFNT-MSC, power output (green curve, left axis), current density (orange curve, right axis), $650{ }^{\circ} \mathrm{C}$, air to the cathode and methane/steam with a ratio of $1 / 2$.

The test demonstrated for the first time that MSCs can operate in methane/steam fuel - in this case over ca. $120 \mathrm{~h}$. The degradation rate during the first ca. $120 \mathrm{~h}$ was rather high, with ca. 30\%/1000 h (see Table I). This fast degradation can be explained by the high, real FU. Even though the fuel flow was set to yield the same FU as in the test with hydrogen (i.e., 10\%, see Figure 9), the real FU was significantly higher. It amounted to ca. $48 \%$ when considering that methane was not completely converted and thus less hydrogen available for the electrochemical reaction. When the FU was further increased, the cell degradation accelerated. This acceleration might be due to the significant increase of FU. In addition, the increase of the current density and thus the increase of electrode overpotential might have an effect, although the increase was only incremental as compared to the first testing period at $48 \%$ FU and the current density was still in the linear range of the $\mathrm{iV}$ curve (see Figure 5). These initial durability tests in hydrogen and methane containing fuel indicate that the degradation starts to accelerate at FUs around 
$50-60 \%$. An electrochemical characterization analysis was carried out in order to identify the origins of this degradation.

\section{Degradation analysis}

When increasing the fuel utilization, the degradation rates increased, both, when using hydrogen and methane containing fuel as well. In order to identify the degradation mechanisms, analysis of EIS recorded under the same ("standard") conditions prior to and after completion of the long-term tests are a useful tool (23). This approach enables comparing the degradation states of cells that were tested under different conditions such as fuel composition or current density. The single processes and their related frequency ranges in the EIS as determined during the gas shift in the initial fingerprint characterization can be used for detailed identification of degradation mechanisms. However, due to the accelerated degradation in the hydrogen test, no final EIS were available. Therefore, a few EIS recorded during the durability test at the period at highest FU were selected and analyzed for both tests. DRT (distribution of relaxation times) analysis was carried out in order to identify the electrode changes due to degradation.

Figure 11 shows EIS recorded during durability test of the LSFNT-MSC in hydrogen immediately after starting the highest FU of $70 \%$ and 220 and $450 \mathrm{~h}$ later, when the degradation rate was more constant and had started to accelerate, respectively (see Figure 9). As observed in Figure 9, the degradation before that accelerated period was not severe. The serial resistance (Figure 11a) did not change significantly. Therefore, degradation through corrosion (breakaway corrosion) or delamination of layers seems not to occur to a large extent. The largest changes occur in the polarization resistance; low and high frequency ranges area affected (see Figure 11a and 11b). Even though the frequency ranges shift as function of the current density, the rough values from the fingerprint at OCV can serve as a guide. Accordingly, the low frequency process is related to anode (steam) gas conversion and diffusion and the high frequency process is related to the anode polarization resistance. Obviously, the high steam content as result of the high FU, has a significant impact on the electrode degradation. At present, detailed degradation studies of this type of anode area lacking. However, the steam partial pressure $p$ H2O was identified as a significant factor for anode degradation as conclusion from comprehensive degradation studies of state-of-the-art Ni/YSZ cermet anodes (e.g., (23)) and can be expected to play a major role in these present cells as well in relation to the Ni particles. Furthermore, higher steam content could promote corrosion of $\mathrm{FeCr}$ particles in the anode backbone and thereby influence the electrochemical reactions at the backbone surface. 

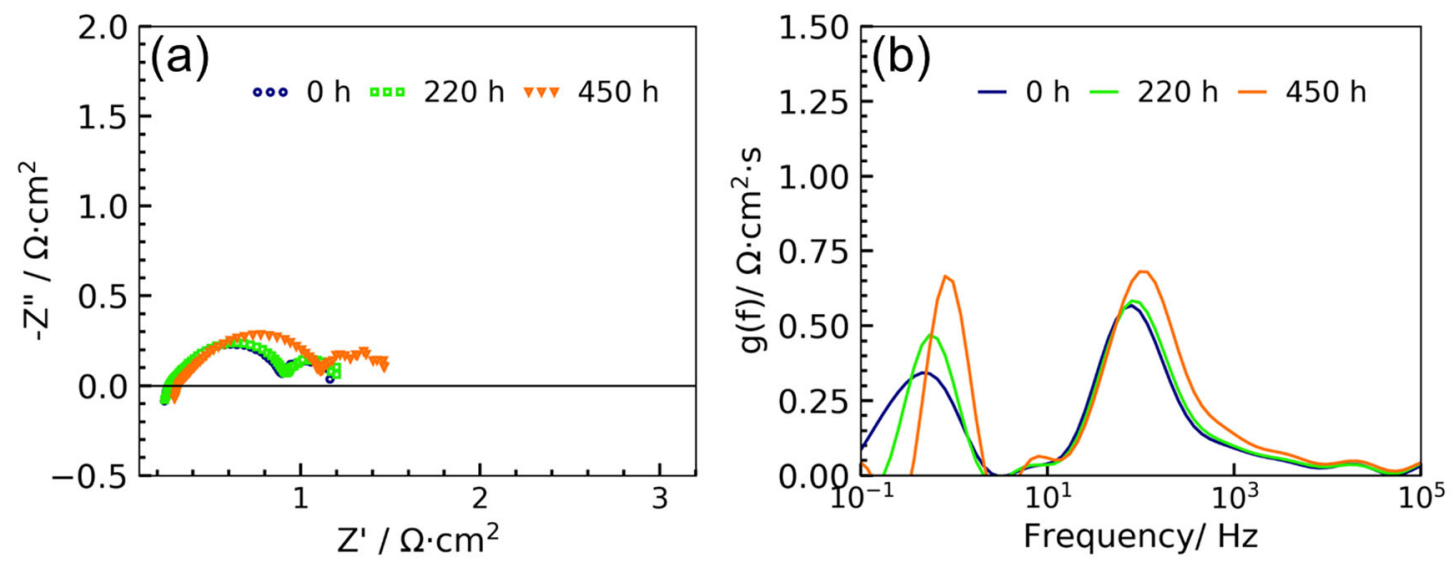

Figure 11. EIS during durability test of the LSFNT-MSC in hydrogen at highest FU of $70 \%$ at $650{ }^{\circ} \mathrm{C}$ immediately after adjusting the gas flow for this $\mathrm{FU}$ and 220 and $450 \mathrm{~h}$ later (for cell voltage trend during this period see Figure 9) (a) Nyquist plot, (b) DRT plot.

Figure 12 shows the EIS results of the LSFNT-MSC test in methane/steam fuel at highest FU. Also in the methane test, the serial resistance did not increase significantly (see Figure 12a). The largest changes are observed in the polarization resistance and here again in the low and in the high frequency region (see Figure 12a and 12b). The anode electrochemical process in the high frequency region degraded significantly in the period of accelerated degradation. This degradation mechanism seems to be occurring in both fuels in a similar way. The low frequency contribution changes seem to be different for the two fuels; they are below $1 \mathrm{~Hz}$ in hydrogen fuel (see Figure 11b) and above $1 \mathrm{~Hz}$ in the methane fuel (see Figure 12b). Furthermore, the increase is more significant in the methane containing fuel. This process is obviously related to the reforming process and the diffusion of the gas mixtures. In case of the methane fuel, a large share of not converted methane is present in the anode layer and is obviously contributing to an increase of the related diffusion resistance. As a consequence, a higher steam content (or more specifically a higher oxygen partial pressure) at the fuel electrode especially at the triple phase boundary (TPB) area is expected than that with $\mathrm{H}_{2} /$ steam fuel, which can lead to accelerated degradation due to the corrosion. An increase of the methane conversion through reforming is thus needed to increase the initial performance / power output and the durability as well. 

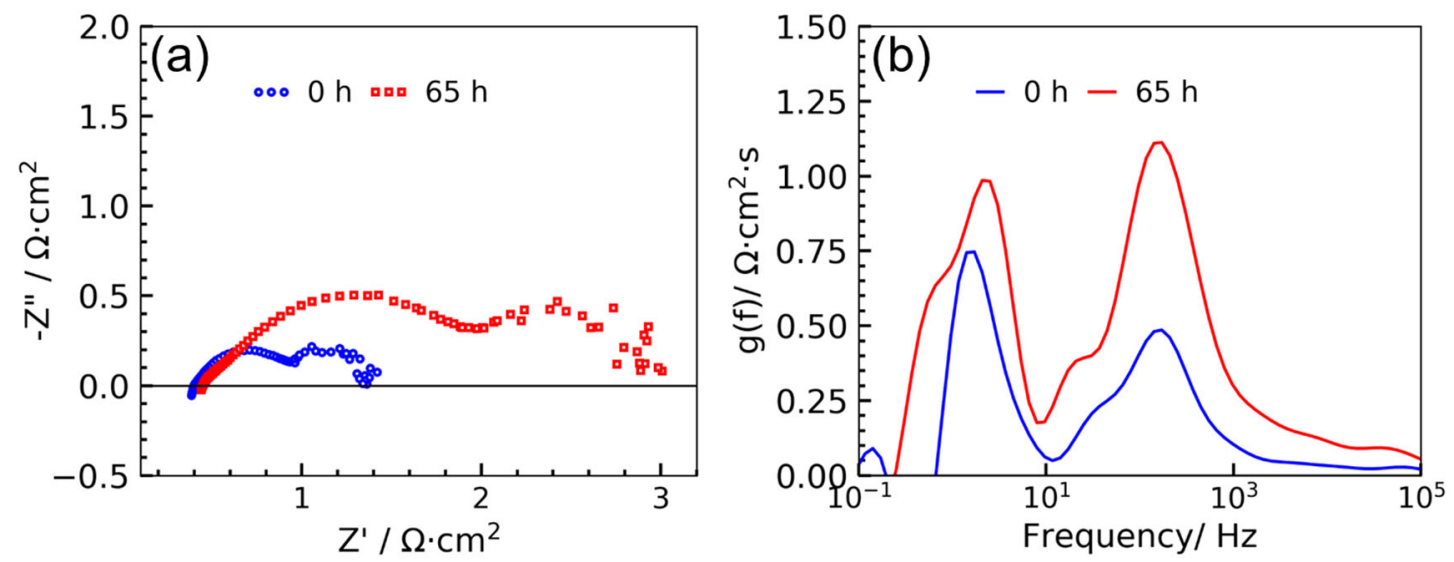

Figure 12. EIS during durability test of the LSFNT-MSC in methane/steam at highest FU of $60 \%$ at $650{ }^{\circ} \mathrm{C}$ immediately after adjusting the gas flow for this $\mathrm{FU}$ and $65 \mathrm{~h}$ later (for cell voltage trend during this period see Figure 10) (a) Nyquist plot, (b) DRT plot.

\section{Summary}

Two types of MSCs were operated in hydrogen/steam and in methane/steam fuel, with the aim to investigate the internal reforming behavior of anodes with either $\mathrm{FeCr}$ YSZ or FeCr-LSFNT backbones, with infiltrated active Ni/GDC particles. As compared to SoA Ni/YSZ anodes, the internal methane reforming is incomplete on the MSC anodes with a Ni content, which is more than a factor of thousand less than in the ceramic Ni/YSZ active anode layers. The MSCs with FeCr-LSFNT backbone showed a higher methane conversion of $17 \%$ and the formed hydrogen acts in the same way as if fueled directly. On the MSC with a FeCr-YSZ backbone, the reforming reaction is more strongly suppressed, to an extent that not only gas conversion / diffusion impedance is increased but also the anode reaction impedance as well.

Direct operation of a MSC with FeCr-LSFNT backbone with methane / steam fuel over in total ca. two hundred hours was demonstrated for the first time. The incomplete methane conversion has to be considered for the calculation of the real FU. The cell was operated at $\mathrm{FU}$ around $50 \%$ and higher. The degradation is most probably related to the resulting high steam content.

If needed in a system context, the reforming activity of the MSCs can be improved by increasing the $\mathrm{Ni}$ content in the anode, by integrating catalytically active stack components such as contact/gas distribution layers (Ni metal foams) or by adding a prereformer prior to the SOFC. A partial internal reforming might be attractive from a system point of few in order to achieve high system efficiencies utilizing the cooling effect of the reforming reaction.

\section{Acknowledgments}


The authors thank K. Brodersen and L. Knudsen for cell manufacture, J. Nielsen and $\mathrm{H}$. Henriksen for very valuable technical assistance for cell testing.

\section{References}

1. R. Leah, A. Bone, E. Hammer, A. Selcuk, M. Rahman, A. Clare, S. Mukerjee, and M. Selby, in Proceedings of the 13th European SOFC \& SOE Forum, Lucerne, Chapter 02, A0302, pp. 13 (2018).

2. D. Udomsilp, F. Thaler, N. H. Menzler, C. Bischof, L. G. J. de Haart, A. K. Opitz, O. Guillon, and M. Bram, J. Electrochem. Soc., 166(8) F506 (2019).

3. F. Thaler, A. Nenning, C. Bischof, D. Udomsilp, L.G.J. de Haart, A.K. Opitz, and M. Bram, ECS Transactions, 91 (1) 887-900 (2019).

4. P.T. Blennow, J. Hjelm, T. Klemensø, Å.H. Persson, K. Brodersen, A.K. Srivastava, H.L. Frandsen, M. Lundberg, S. Ramousse, and M.B. Mogensen, ECS Trans., 25(2), 701 (2009).

5. T. Klemensø, J. Nielsen, P. Blennow, Å. H. Persson, T. Stegk, P. Hjalmarsson, B. H. Christensen, S. Sønderby, J. Hjelm, and S. Ramousse, ECS Trans., 35(1) 369 (2011).

6. H.E. Evans, A.T. Donaldson, T.C. Gilmour, Oxid. Met., 52, 379 (1999).

7. B. J. McKenna, N. Christiansen, R. Schauperl ,P. Prenninger, J.Nielsen, P. Blennow, T. Klemensø, S. Ramousse, A. Kromp, and A. Weber, Fuel Cells, 13(4), 592 (2013).

8. J. Froitzheim, L. Niewolak, M. Brandner, L. Singheiser, W. J. Quadakkers, J. Fuel Cell Sci. Technol., 7, (2010).

9. L. Garcia-Fresnillo, V. Shemet, A. Chyrkin, L. G. J. de Haart, W. J. Quadakkers, J. Power Sources, 271, 213 (2014).

10. A. Harthoj, H. Alimadadi, T. Holt, P. Moller, J. Electrochem. Soc., 162, F387 (2015).

11. B. R. Sudireddy, J. Nielsen, A. H. Persson, K. Thyden, K. Brodersen, S. Ramousse, D. Neagu, E. Stefan, J. T. S. Irvine, H.Geisler, A.Weber, G. Reiss, R. Schauperl, J. Rechberger, J. Froitzheim, R. Sachitanand, H. Falk-Windisch, J. E. Svensson, M. W. Lundberg, R. Berger, J.Westlinder, S. Hornauer, and T. Kiefer, Fuel Cells, 17(4), 508 (2017).

12. J. Nielsen, Å. H. Persson, B. R. Sudireddy, and J.T.S. Irvine, K. Thydén, J. Power Sources, 372, 99 (2017).

13. Å. Persson, in "Effective corrosion protection coatings for metal supported solid oxide fuel cell $\mathrm{FeCr}$ composite based anodes", in preparation.

14. Fuel Cells Bulletin, (7), 2 (2016).

15. Y. Bessekon, P.Zielke, A. C. Wulff, and A. Hagen, Int. J. Hydrogen Energy, 44(3), 1905 (2919).

16. J. Nielsen, T. Klemensø, and P. Blennow, J. Power Sources, 219, 305 (2012).

17. J. Nielsen, P. Hjalmarsson, M. H. Hansen, and P. Blennow, J. Power Sources, 245, 418 (2014).

18. C. Graves, RAVDAV data analysis software, (2012).

19. A. Kromp, J. Nielsen, P. Blennow, T. Klemensø, A. Weber, Fuel Cells, 13, 598 (2013).

20. G. Tsekouras, D. Neagu, J.T.S. Irvine, Energy Environ. Sci., 6, 256 (2012). 
21. D. Neagu, G. Tsekouras, D.N. Miller, H. Ménard, J.T.S. Irvine, Nat. Chem., 5, 916 (2013).

22. P. Zielke, A. C. Wulff, X. Sun, S. H. Jensen, R. Kiebach, H. L. Frandsen, P. Norby, and A. Hagen, Fuel Cells, 17(5), 730 (2017).

23. A. Ploner, A. Hagen, and A. Hauch, Fuel Cells, 17(4), 498 (2017). 